\title{
22. FRACTURE DISTRIBUTION FROM DOWNHOLE ELECTRICAL IMAGES AT THE BASE OF THE SHEETED DIKE COMPLEX IN HOLE 504B'
}

\author{
Mariem Ayadi, ${ }^{2,3}$ Philippe A. Pezard,,$^{2.3}$ and François Dominique de Larouzière ${ }^{2}$
}

\begin{abstract}
Downhole electrical images obtained in the bottom $200 \mathrm{~m}$ of Hole 504B during ODP Leg 148 are analyzed here in terms of geometry, with a precise description of fracturing given. Because core recovery was poor, these images are essential to the understanding of the structural context within which this deep hole is drilled. Nearly 4500 traces of fractures were mapped over $167 \mathrm{~m}$ of images ( 26.9 per $\mathrm{m}$ on average). The steep to nearly vertical structures that dominate throughout this interval are oriented mainly in a $015^{\circ} \mathrm{N}$ strike direction, which is identical to the maximum horizontal stress $\left(\mathrm{SH}_{\max }\right)$ determined higher up in Hole 504B from BHTV images.

Two zones with intense horizontal fracturing are described (1920-1950 and 1975-2005 mbsf) from FMS images. Although the top one is also detected at a meter scale by deep-reaching electrical resistivity measurements, the bottom one is not. The top interval is also the site of a change in hole deviation (at $1950 \mathrm{mbsf}$ ), possibly in relation to a change in dike orientation or in structure of the stress field near the bottom of the hole.

The large number of nearly vertical fractures reported from FMS images in this bottom section were probably induced in response to drilling. Particularly concentrated over a 70-m-long interval (1975-2045 mbsf), these steep features coincide in azimuthal direction with those of borehole enlargements. This might arise from tension-generated failures under a strike-slip and strongly deviatoric environment, as suggested also by modes of failure obtained in cores. In such a case, borehole enlargements developed in the direction of tensile failure and pointing $015^{\circ} \mathrm{N}$ would not correspond to the traditional "breakout" terminology, but would confirm the previous determination of $\mathrm{SH}_{\max }$ orientation in this hole.

From 1980 to $2003 \mathrm{mbsf}$, steep features are also detected at depth into the rock from electrical measurements. Located at the bottom of the section drilled during Leg 140, this interval is that in which cooling from fluid circulation was applied at the beginning of Leg 148 in order to protect the core bit from high temperatures. Therefore, it is likely that borehole enlargements and nearly vertical fracturing detected from 1975 to $2045 \mathrm{mbsf}$ originate in drilling, as the propagation of failures deep into the diabase is particularly efficient at depths where cooling was specifically performed.
\end{abstract}

\section{INTRODUCTION}

Site 504 is located on 5.9-m.y.-old crust, $201 \mathrm{~km}$ south of the Costa Rica Rift, the easternmost of three segments forming the "Galapagos" or "Cocos-Nazca" spreading center. The Costa Rica Rift spreads asymmetrically at an intermediate rate (a half-rate of $3.6 \mathrm{~cm} /$ $\mathrm{yr}$ to the south and $3.0 \mathrm{~cm} / \mathrm{yr}$ to the north; Hey et al., 1977). The basement relief south of Costa Rica Rift (Nazca Plate) results from the presence of east-west normal faults parallel to the rift axis. This faulting produces north-dipping half-graben structures with blocks tilted less than $5^{\circ}$ and separated by ridges 1 to $2 \mathrm{~km}$ wide (Langseth et al., 1988). Site 504 is located at the center of a spreading segment. This is significant in terms of magmatic and tectonic processes, which affects locally hydrothermal alteration processes and the physical structure of the investigated crust.

The primary objective of Leg 148 was to revisit Deep Sea Drilling Project/Ocean Drilling Program (DSDP/ODP) Hole 504B in the eastern equatorial Pacific (Langseth et al., 1983) and deepen it through the dike/gabbro transition. Before Leg 148, Hole 504B was already the deepest scientific drillhole in the oceans, extending $2000.4 \mathrm{~m}$ below seafloor (mbsf) under $3460 \mathrm{~m}$ of water. Currently, it is the only

'Alt, J.C., Kinoshita, H., Stokking, L.B., and Michael, P.J. (Eds.), 1996. Proc. ODP. Sci. Results, 148: College Station, TX (Ocean Drilling Program).

${ }^{2}$ Laboratoire de Mesures en Forage, Institut Méditerranéen de Technologie, Technopôle de Château-Gombert, F-13451 Marseille Cedex 20, France. Ayadi: ayadi@imtmerl.imt-mrs.fr; Pezard: pezard@imtmerl.imt-mrs.fr; de Larouzière: fdl@imtmerl.imt-mrs.fr

'Laboratoire de Pétrologie Magmatique, URA CNRS 1277, Faculté des Sciences et Techniques de Saint-Jérôme, Avenue Escadrille Normandie-Niemen, F-13397 Marseille Cedex 20. France. hole to penetrate through the volcanic section into the underlying sheeted dike complex, and Site 504 has over the years become the in situ reference section for the physical and chemical structure of the upper oceanic crust. Before Leg 148, six DSDP and ODP legs contributed to the 2000.4-mbsf penetration in Hole 504B (Fig. 1). The hole has drilled through $274.5 \mathrm{~m}$ of sediments; a $571.5 \mathrm{-m}$ volcanic section consisting of pillow, massive flows, breccias, and a few dikes; a 209-m transition zone from extrusives into intrusives; and $945.4 \mathrm{~m}$ of dikes and massive units, interpreted to constitute the sheeted dike complex. Core recovery averaged $29.8 \%$ in the volcanic section and $14.3 \%$ in the sheeted dikes at the end of Leg 140. During Leg 148, an additional $110.6 \mathrm{~m}$ was drilled through massive diabases, penetrating from 2000.4 to $2111.0 \mathrm{mbsf}$, for an average recovery of $10.4 \%$. The recovered rocks are a continuation of the sheeted dike complex drilled on previous legs.

Because of the very low core recovery near the bottom of the hole, continuous and high-resolution borehole wall images produced by the Schlumberger Formation MicroScanner (FMS) tool recorded during Leg 148 are essential to the analysis and understanding of the structure of this unique deep section of the oceanic crust. At the end of Leg 148, the FMS was lowered to the bottom of Hole 504B, and the recording started normally at 2079 mbsf, at an upward logging speed of $600 \mathrm{~m} / \mathrm{hr}$. After only $14 \mathrm{~m}$ of recording, the downhole sensor became stuck and the sonde had to be closed to pass through a hole restriction. Recording resumed at 2056 mbsf and continued up to $1885 \mathrm{mbsf}$. Unfortunately, one of the electronic channel multiplexers in the sonde failed near $2056 \mathrm{mbsf}$, probably because of high temperatures at this depth, and good data from only three pads were recorded above that. Again owing to poor hole conditions, the data above 1856 mbsf were broken into three segments covering the following 


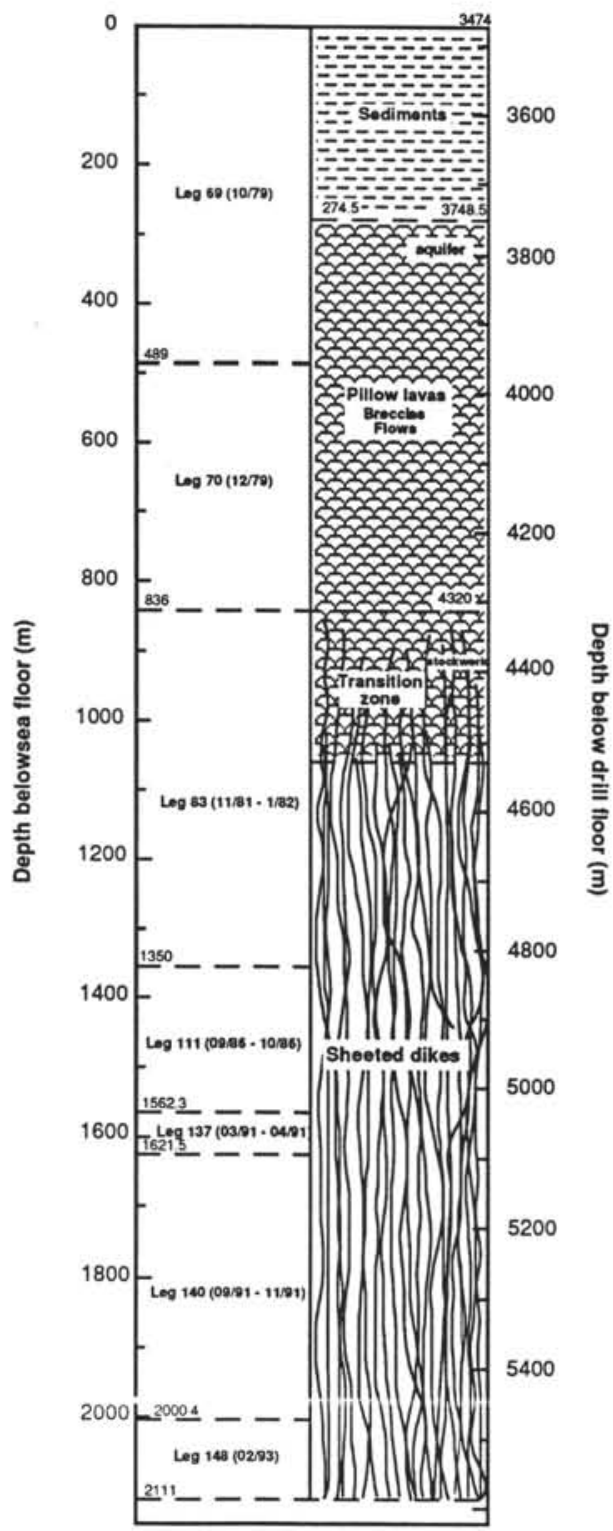

Figure 1. Schematic of Hole 504B drilling history and lithostratigraphy after Leg 148. The depth is given both in $\mathrm{m}$ below seafloor, as well as in $\mathrm{m}$ below drill floor.

intervals: 1856-1098, 1090-995, and 977-293 mbsf. A total length of $1721 \mathrm{~m}$ of electrical images was consequently recorded over 1805 $\mathrm{m}$ of basement available for logging, which constitutes a considerable data set.

\section{Stress Field and Fracture Distribution}

The presence of an elliptical borehole shape is traditionally interpreted in terms of breakouts (Bell and Gough, 1979), with the long axis of the borehole pointing toward the minimum horizontal stress direction. From the analysis of borehole televiewer (BHTV) acoustic images of the borehole wall in the upper part of the hole, Newmark et al. (1985) and Morin et al. (1990) derived a main mode of ellipticity pointing $114^{\circ} \mathrm{N}$. This direction was proposed to represent the local minimum horizontal stress direction. The structure of stress field in at Site 504 has been determined as either compressive or strike-slip in nature from the analysis of BHTV images (Moos and Zoback,
1990) and the presence of ruptured surfaces in the core from the deeper sections (Alt, Kinoshita, Stokking, et al., 1993).

This paper deals with the lowermost section of the hole (from 2077 to $1900 \mathrm{mbsf}$ ). The images are analyzed in terms of geometry with a description of fracturing vs. depth.

\section{CORE OBSERVATIONS}

The interpretation of basement structure near Hole 504B as tilted blocks (Langseth et al., 1988) is supported by an approximately eastwest strike, and by steep northward dips determined for two dikes from Leg 140 (Dick, Erzinger, Stokking, et al., 1992). All samples recovered in Leg 148 show well-preserved primary (igneous) characteristics (Alt, Kinoshita, Stokking, et al., 1993). No shape fabric or preferred orientation of grains related to crystal-plastic deformation has been found. Observed structures include veins, fractures, chilled margins, and rare cataclastic zones. Veins are nearly all filled by actinolite and chlorite, with no clear crosscutting relations. Their average dips group in two sets and are very similar to those recovered in Leg $140\left(20^{\circ}-27^{\circ}\right.$ and $75^{\circ}-90^{\circ}$; Dick, Erzinger, Stokking, et al., 1992).

Fractures are the dominant structure in the core recovered during Leg 148, and consist of the following: (1) open fractures; (2) chloritecoated open fractures; and (3) microfaults. Open fractures observed in the core tend to have gentle or steep dips, and might have been generated during drilling. Microfaults are common in the core of Leg 148 , though they were not observed commonly in the Leg 140 core. The microfaults are lineated with steps, commonly discontinuous, and show no resolvable displacement in thin section. Microfaults are most abundant from 2026 to 2052 mbsf, where recovery was particularly low. Faulting might therefore be expected over this interval, as well as at the bottom of Hole 504B (2103-2111 mbsf). On a macroscopic scale, the oriented margins and the microdikes are steeply dipping $\left(76^{\circ}-88^{\circ}\right)$, the one paleomagnetically reoriented margin has a strike of $118^{\circ}$ and dips $84^{\circ}$ to the south. This strike has considerable uncertainty, however, because only a small area of chilled material was attached to the rounded face of the core, making azimuthal measurement difficult.

\section{DOWNHOLE MEASUREMENTS}

During Leg 148, a series of downhole measurements including Schlumberger geophysical sensors, the FMS, a magnetometer, a temperature sensor, and a vertical seismic profile (VSP) were successfully conducted in Hole 504B (Alt, Kinoshita, Stokking, et al., 1993). Below $1900 \mathrm{mbsf}$, the temperature gradient is about $49^{\circ} \mathrm{C} / \mathrm{km}$. The profile is linear, and the temperature reaches a recorded maximum of $197^{\circ} \mathrm{C}$ at about $2086 \mathrm{mbsf}$. Compressional-wave velocity log data reach $6.8 \mathrm{~km} / \mathrm{s}$ in the considered interval (Fig. 2), decreasing near $1910,1925,1985$, and 2005 mbsf, where electrical resistivity values are also low, probably caused by the presence of fractures. The natural radioactivity profile (GR) barely shows any character owing to the extremely low radioactivity of the formation, close to the detection level of the sensor.

\section{Electrical Resistivity}

The electrical resistivity was measured at meter scale throughout basement with a lateral device, the Schlumberger dual laterolog (DLL) tool (Ellis, 1987). FMS electrical images of the borehole surface were also obtained along the entire basement. The conduction may be electrolytic for porous space and fluid-filled fractures, or surfacic with exchange of cations for altered rocks. Lateral devices are largely influenced by anisotropy and are accurate at high resistivity values (with an error of a few percents up to $40.0 \Omega \mathrm{m}$ for the DLL), 
such as those obtained in crystalline formations. The physical principle of the DLL is to measure a variable potential modulated by the intensity of a variable current used to focus in a $60-\mathrm{cm}$-thick cylindrical beam (Ellis, 1987). This current flows from a downhole electrode to a remote return, and the sensor is designed to provide, at two different frequencies ( 35 and $280 \mathrm{~Hz}$, respectively), two measurements of electrical resistivity referred to as deep (LLd) and shallow (LLs), owing to their respective horizontal penetration into the rockPorosity Estimates

Several estimates of porosity may be obtained from DLL data. One can be derived from the deep penetrating measurement (LLd), which is less sensitive to borehole effects than the shallow one (LLs) and, as such, may be considered as representative of the total porosity of the rock when derived from Archie's formula (Archie, 1942; Brace et al., 1965; Becker, 1985). An estimate of "total porosity" from resistivity (referred as $\emptyset_{\mathrm{a}}$ in the following) is then obtained, although the LLd is mostly sensitive to the horizontal resistivity of the rock, hence affected where subhorizontal conductive fractures are present.

A second porosity estimate can be obtained from the difference between the two DLL measurements (Pezard and Anderson, 1990). Because of the tool geometry and strong focusing, the presence of subhorizontal conductive features decreases the deep measurement more than the shallow one. In contrast, the deep resistivity measurement (LLd) always reads higher values than the shallow one (LLs) in front of subvertical structures. This method consequently provides an estimate of porosity in strongly anisotropic media. The estimate is, however, a minimum one because of potential conflicting effects of horizontal $\left(\emptyset_{\mathrm{h} \text {-DLL}}\right)$ and vertical $\left(\emptyset_{\mathrm{v} \text {-DLL }}\right)$ structures that may cancel out to give a minimum estimate only of, in our case, overall fracture porosity $\left(\emptyset_{\mathrm{t}-\mathrm{DLL}}\right)$. In fact, porosity is a scalar and not a vector. Therefore, the term "horizontal porosity" (for example) is used to allude to the overall orientation of high aspect ratio "subhorizontal" conductive pore space detected with the DLL.

In the considered interval (1900-2077 mbsf), resistivity data recorded with the DLL show the highest values of electrical resistivity obtained within Layer 2C basalts in Hole 504B (Pezard et al., this volume), with $6000 \Omega \mathrm{m}$. The large and unexpected difference between the shallow (LLs) and deep (LLd) measurements obtained throughout this interval (Fig. 2) suggests the dominating presence of subvertical features. This difference is obtained in spite of corrections made to both measurements to compensate for additional hole conductivity associated with the eventual presence of borehole enlargements.

In the dikes of Hole 504B, clay minerals were found to contribute substantially to the overall conductivity of the rock as a result of surface conductivity, and cannot consequently be neglected with respect to seawater conductivity (Pezard, 1990; Revil et al., this volume). To account for this surface conductivity, and to estimate the fraction of the rock opened to fluid circulation, another porosity estimate referred to as $\varnothing_{\mathrm{c}}$, and also based on the deep measurement (LLd), was computed (Pezard et al., this volume). The values of $\emptyset_{a}$ from Archie's formula (1942) and $\varnothing_{\mathrm{c}}$ are both presented over the considered interval in Figure 3.

\section{Results}

Although clay minerals appear to account for $60 \%$ to $80 \%$ of the derived porosity, the total porosity ranges from $0.5 \%$ to $1.0 \%$ on average (Fig. 3), which is in good agreement with measurements made on cores (Alt, Kinoshita, Stokking, et al., 1993). The main feature in the analyzed interval appears to be a pair of sudden increases in porosity estimates, at 1926 and 1935 mbsf (Fig. 3). The abruptness of these events, as well as the "reversal" in resistivity profiles (with LLs $>$ LLd locally), indicates the presence of a pair of subhorizontal structures, which is confirmed in the case of the bottom one (1935 mbsf) only by the "horizontal fracture porosity" estimate derived from the DLL $\left(\emptyset_{\mathrm{h}-\mathrm{DLL}}\right)$. This may suggest the presence of two subhorizontal faults (1926 and $1935 \mathrm{mbsf}$ ) in the vicinity of a change in the hole deviation rate (near $1950 \mathrm{mbsf}$ ), the only one of this magnitude in the

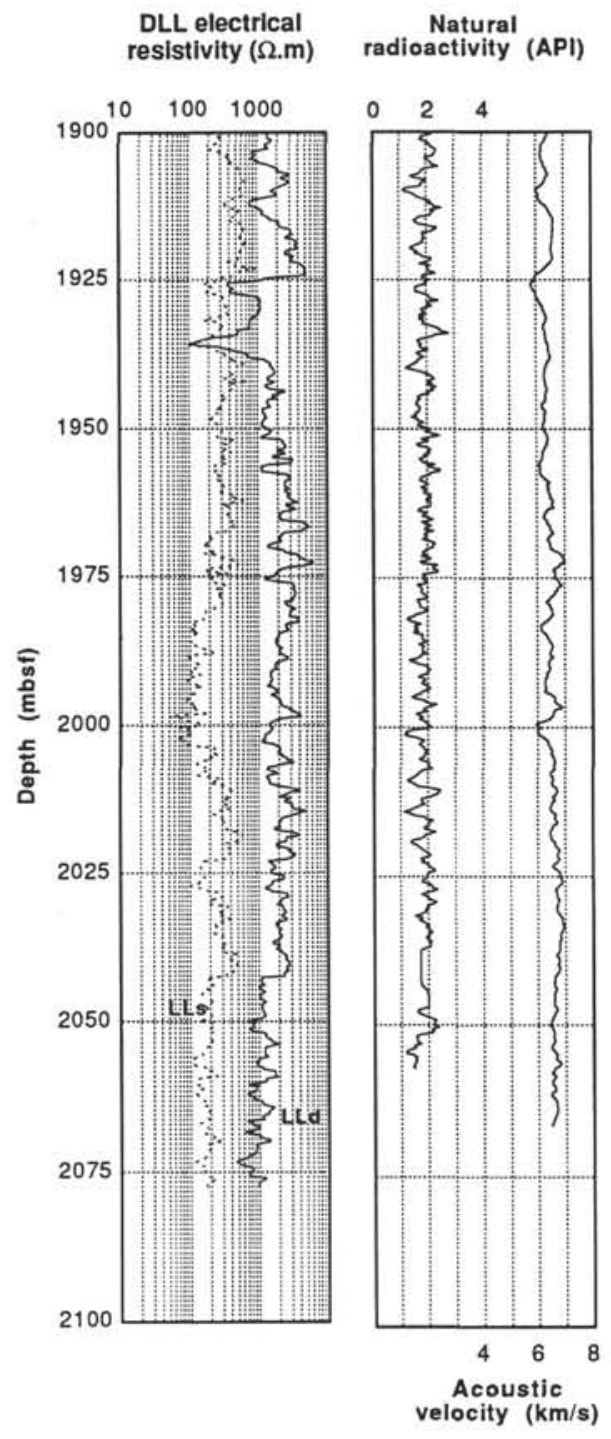

Figure 2. Electrical resistivity measurements (to the left), recorded with the dual laterolog tool in the sheeted dike complex, over the lower $200 \mathrm{~m}$ of Hole $504 \mathrm{~B}$. Natural radioactivity and acoustic velocity profiles are presented to the right.

entire sheeted dike complex (Fig. 4). The depth discrepancy between these two events might be related to the arrangement of stabilizers in the bottom-hole assembly while coring this section.

The size, shape, and borehole deviation with respect to north are obtained from calipers and data recorded within the inclinometry section of the FMS (Fig. 5). The hole deviation from vertical is generally less than $6^{\circ}$, which ensures the proper functioning of the imaging tool. The deeper section of the Hole 504B is characterized by the presence of large breakouts, with values up to $35 \mathrm{~cm}$ (14 in.) in the long axis direction, whereas the short axis usually stays at bit size $(21.6 \mathrm{~cm})$.

Relatively high values of "vertical fracture porosity" $\left(\emptyset_{\mathrm{v} \text {-DLL }}\right)$ averaging $0.8 \%$ are obtained between 1980 and 2010 mbsf from DLL data analysis, which indicates a strong subvertical orientation of the conducting pathway in this zone. Subhorizontal structures generally appear to dominate over the considered interval, although relatively low values are obtained in the upper $50 \mathrm{~m}$. Together with the sudden change in hole deviation at about 1950 mbsf (Fig. 4), this strong subvertical signal can be interpreted as indicative of a change in stress regime or structure orientation at about $1930 \mathrm{mbsf}$. 


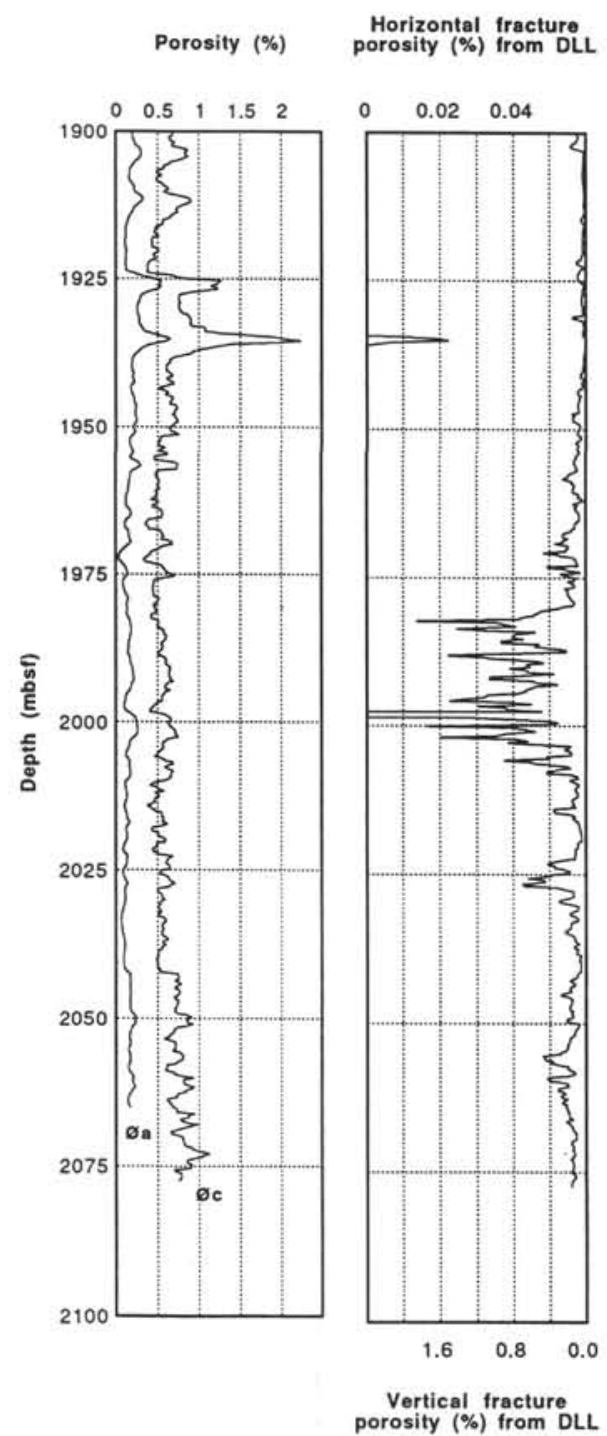

Figure 3. To the left are estimates of the total porosity derived from Archie's (1942) formula (for the larger values) and of porosity open to fluid circulation. To the right are horizontal and vertical fracture porosities derived from the DLL.

With an either compressive or strike-slip stress regime (Moos and Zoback, 1990), the strong subvertical signal inferred from DLL electrical measurements throughout, in particular below $1950 \mathrm{mbsf}$, would consequently favor the presence of a strike-slip regime. The large deviatoric component of this field, with the minimum horizontal component similar to the vertical one, but possibly half of the maximum horizontal component (T. Roeckel, unpubl. data), if sufficient to initiate rock failure in relation with the drilling of the hole, could explain the presence of the numerous subvertical conductive pathways detected with the DLL.

\section{FMS IMAGE ANALYSIS}

The FMS analysis in the sheeted dike complex of Hole 504B has been restricted here to the interval spanning 1900 to 2079 mbsf. This restriction was imposed upon us as the FracView software used for the analysis was made available for only two months. Except for the bottom $14 \mathrm{~m}$, where all four images were obtained, FMS images con-

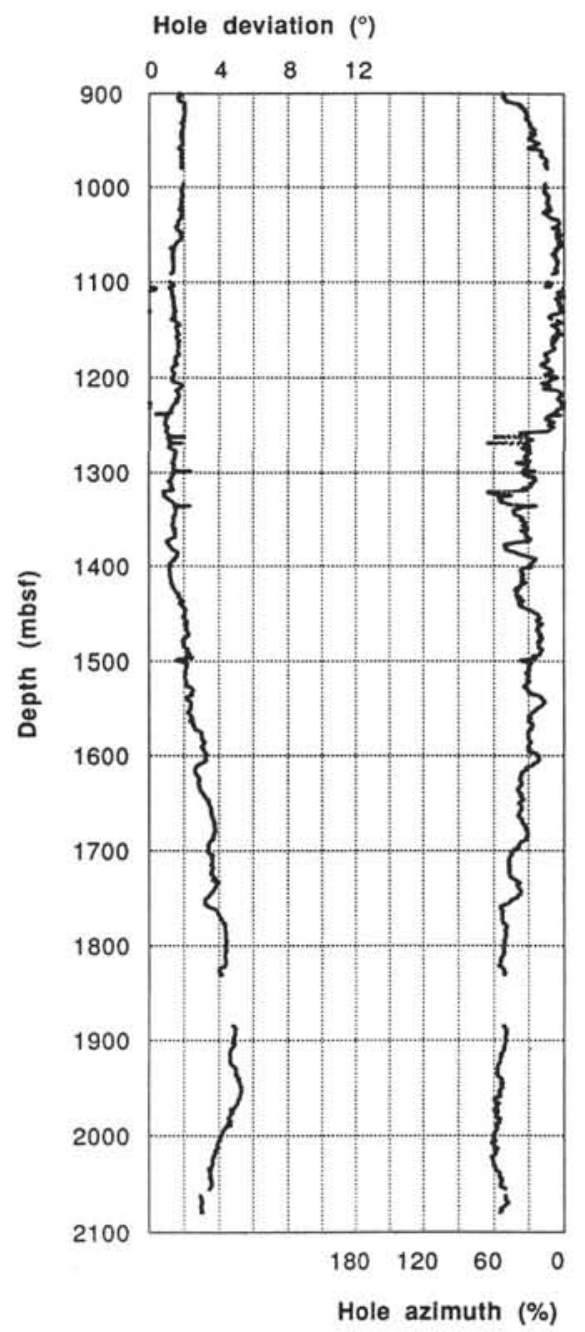

Figure 4. Hole deviation and azimuth derived from the inclinometry module of the FMS, presented from the top of the sheeted dike complex in Hole 504B.

sist only of three images over this interval, covering on average $15 \%$ of the surface of the hole at this depth.

\section{The Tool}

The Formation MicroScanner creates a picture of the borehole wall by mapping its resistivity using an array of small, pad-mounted electrodes (Lüthi and Banavar, 1988). The slimhole configuration developed for ODP (Pezard et al., 1990) uses four pads, each with 16 buttons (Fig. 5). A single pass of the tool maps about $22 \%$ of the 25.4 $\mathrm{cm}$-diameter (10 in.) borehole. Each electrode is oriented in space with three-axis accelerometers and fluxgate magnetometers, making it possible to derive the strike and dip of geological structures. During logging, current flows from the lower section of the tool into the rock formation, then to a return electrode located at the top of the sonde. A constant difference of electrical potential is held between each of the electrodes and the remote return. As the conductivity of the rock formation varies in front of each electrode during recording, a variable current is injected for each electrode into the rock to satisfy the constant potential condition.

Because of electrode geometry, the tool has a moderately shallow depth of investigation (a few centimeters beyond the borehole wall). FMS data are recorded each $2.5 \mathrm{~mm}$ as the tool moves up the bore- 


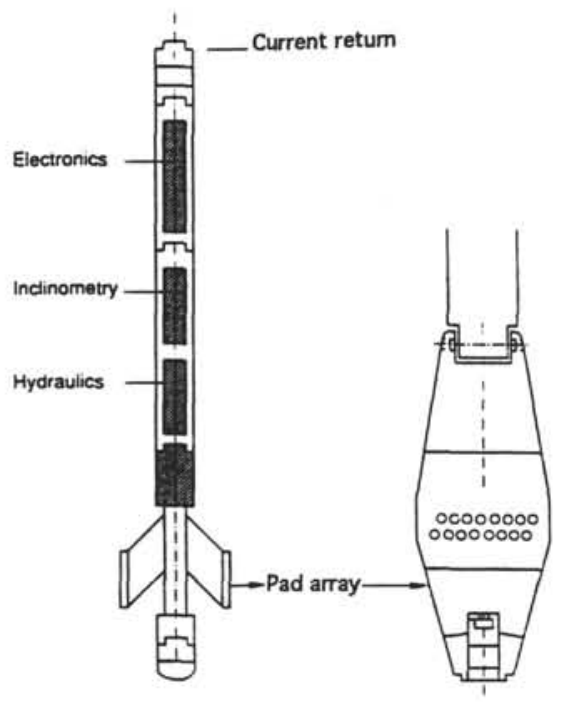

Figure 5. Sketch of the formation microscanner tool from Pezard et al. (1990).

hole, and the vertical resolution of individual features is about $1 \mathrm{~cm}$. The tool can, however, detect thinner features provided that they have sufficient resistivity contrast to the surrounding matrix. The images recorded with the FMS show conductivity changes, particularly those resulting from beds different in nature, as well as the presence of fractures, either open or mineralized.

\section{Data Processing}

Data processing (using LogoS software of Schlumberger) is required to convert the raw data into a gray-scale (or color-scale) image representative of conductivity changes. Data processing includes conversion of the current intensity to variable-intensity gray or color images. In the former, black is lowest resistivity and white is highest resistivity. As the "constant" difference of potential is regulated in the tool to vary, the images do not represent a direct map of electrical conductivity of the borehole wall. The button current is thus recorded as a series of curves that represent relative changes in microresistivity caused by either (1) varying electrolytic conduction as a function of fluid type and changes in grain and pore volume, size, and geometry or (2) cation exchange on the surfaces of clay minerals and other conductive minerals.

\section{FMS Image Analysis}

The images were analyzed on a SUN workstation using FracView, a Schlumberger interpretative software that allows the interactive display and analysis of oriented images. The fracture analysis method used in FracView is presented in Lüthi and Souhaité (1990) and, beyond detection and mapping, is aimed at providing a quantitative evaluation of the "fracture aperture" from electrical images. In this paper, we are interested only in the geometrical aspect (azimuth and dips) of the detected planes.

Mapping fractures on FMS images consists of finding traces showing a contrast of conductivity to the surrounding rock. Any plane intersected by a cylindrical borehole is represented by a sinusoid on a depth-azimuth plot. The dip angle is related to the amplitude of the sinusoid, and the dip direction (plunge) is given by the lowermost point of the trace. Traces up to $80^{\circ}-85^{\circ}$ dip can be found on all images. For features with greater dip, if a fracture is nearly vertical, it is typically visible on one image only, as shown at $2075 \mathrm{mbsf}$ for the $105^{\circ} \mathrm{N}$-pointing pad (Fig. 6). Potential fractures are determined as

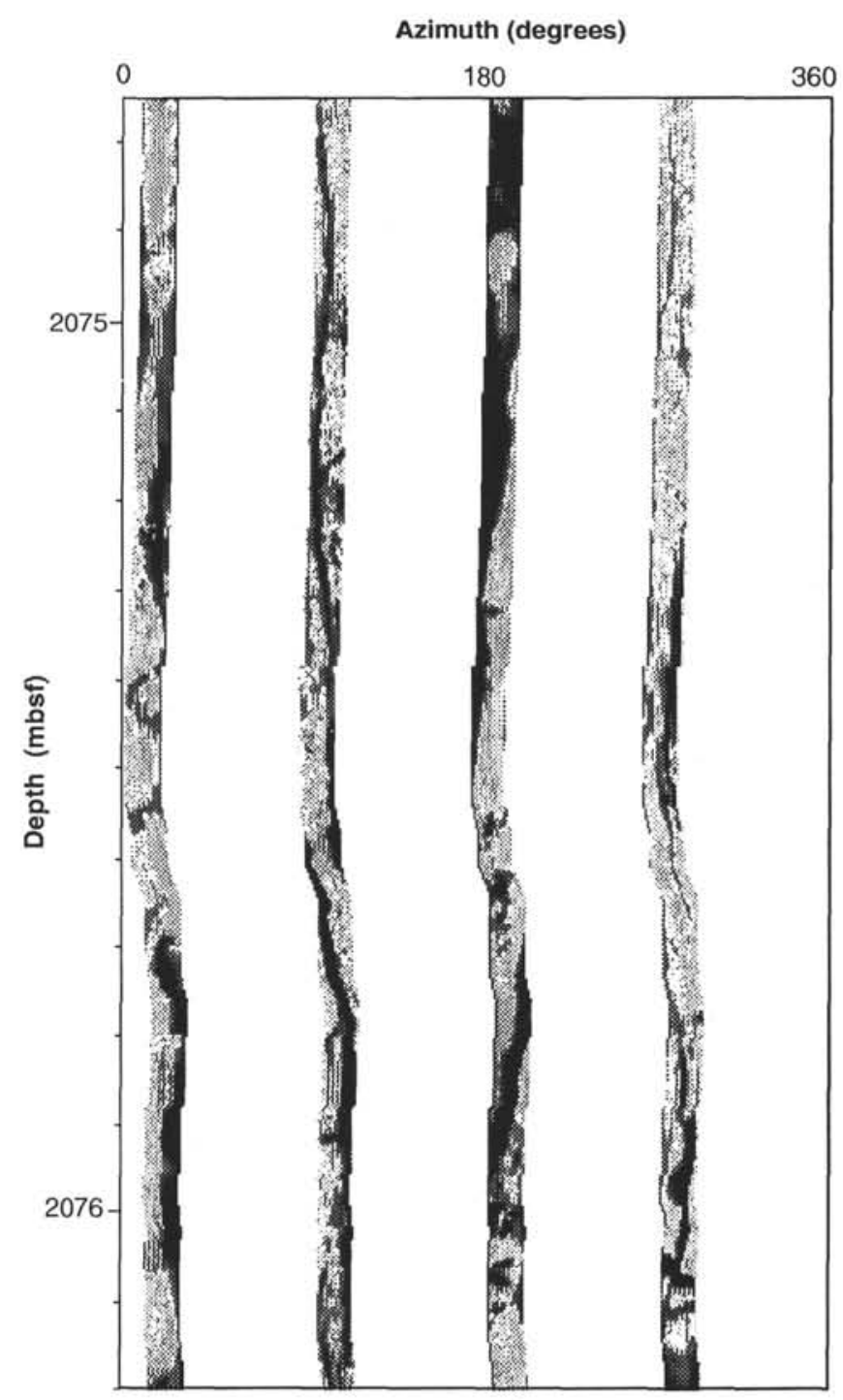

Figure 6. Azimuthal FMS images from 2072 to 2079 mbsf in Hole 504B.

locations where conductivity values exceed the local matrix conductivity by a statistically significant amount. Line sharpening and trace connectivity tests are performed to trace the fractures after manual identification. Although the structures observed in the core (veins, open fractures, microfaults, induced fractures, etc.) cannot be distinguished directly from FMS images because they are represented only in terms of electrical conductivity, a first-order classification in terms of geometry can be made.

\section{Results}

About 4500 traces of fracture planes were mapped between 1900 and 2079 mbsf. All of them are represented in terms of dip azimuth (plunge direction) in Figure 7, and no obvious trend vs. depth is obtained at this scale. However, a large number of fractures was mapped in the 1920-1950 mbsf interval and also near $2000 \mathrm{mbsf}$. To organize this large data set, the fracture traces were classified in terms of dip angle as subhorizontal (dip $\left.<30^{\circ}\right)$, "intermediate" $\left(30^{\circ} \leq\right.$ dip $<$ $\left.60^{\circ}\right)$, subvertical $\left(60^{\circ} \leq \operatorname{dip}<85^{\circ}\right)$, and steep $\left(\operatorname{dip} \geq 85^{\circ}\right)$ fracture sets. The boundaries between these four sets were defined somewhat arbitrarily but also with a goal to compare FMS-derived "fracture density profiles" to that computed from DLL data. 


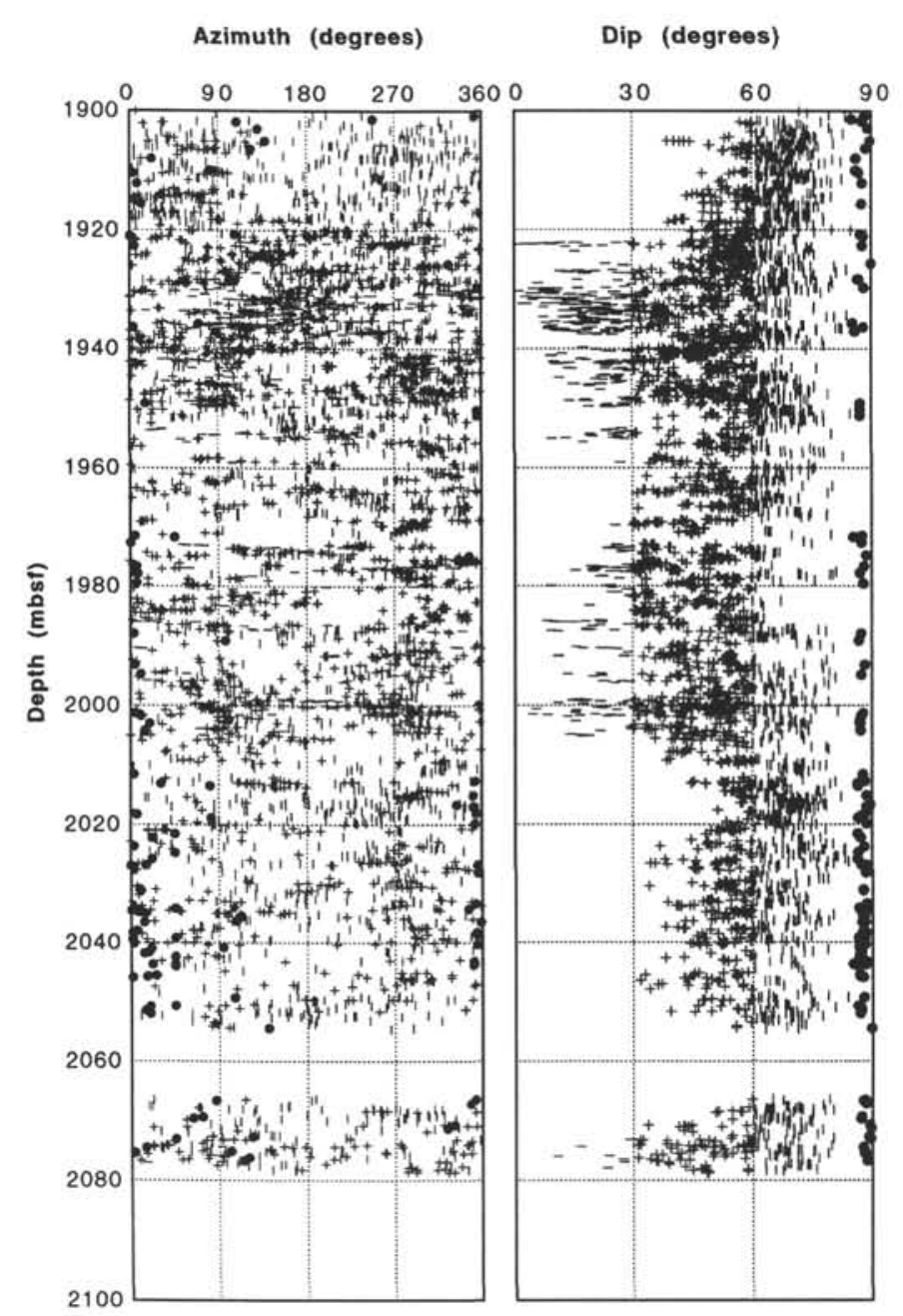

Figure 7. Depth-azimuth and depth-dip diagrams for the 4500 traces identified with the FracView software from FMS images in the bottom $200 \mathrm{~m}$ of Hole 504B. Subhorizontal (dip $<30^{\circ}$, horizontal bars), "intermediate" $\left(30^{\circ} \leq\right.$ dip $<60^{\circ}$, plus sign), subvertical $\left(60^{\circ} \leq\right.$ dip $<85^{\circ}$, vertical bars), and steep fractures (dip $\geq 85^{\circ}$, solid circle) are distinguished by different symbols.

As already found from DLL data analysis (Fig. 3), intermediate and subvertical fractures dominate over the entire interval (Fig. 7), whereas subhorizontal features are present in two zones only: from 1920 to 1950 mbsf and from 1975 to 2005 mbsf. From this observation, and for the purpose of further analysis, the entire section was divided into five depth zones: Zone A = 1900-1920 mbsf, Zone B = 1920-1950 mbsf, Zone C $=1950-1975$ mbsf, Zone $\mathrm{D}=1975-2005$ mbsf, and Zone $\mathrm{E}=$ 2005-2080 mbsf (Fig. 8).

Because of a peak in dip azimuth (plunge direction) toward $300^{\circ} \mathrm{N}$, a slight trend in mean strike orientation is obtained at about $030^{\circ} \mathrm{N}$ for the global set (4500 events). The trend is somewhat evenly distributed elsewhere (Fig. 9). Individual families of subhorizontal (538 planes), intermediate ( 2107 planes), and subvertical features ( 1651 planes) are better organized in space. In the case of subhorizontal features, three distinct strike directions are obtained $\left(030^{\circ} \mathrm{N}\right.$, $120^{\circ} \mathrm{N}$, and $160^{\circ} \mathrm{N}$ ). However, the main characteristic of this distribution is given by the histogram of azimuth, with only a few planes dipping from $300^{\circ} \mathrm{N}$ to $050^{\circ} \mathrm{N}$. Intermediate features provide a main strike direction oriented $030^{\circ} \mathrm{N}$, whereas subvertical features trend $015^{\circ} \mathrm{N}$ on average.

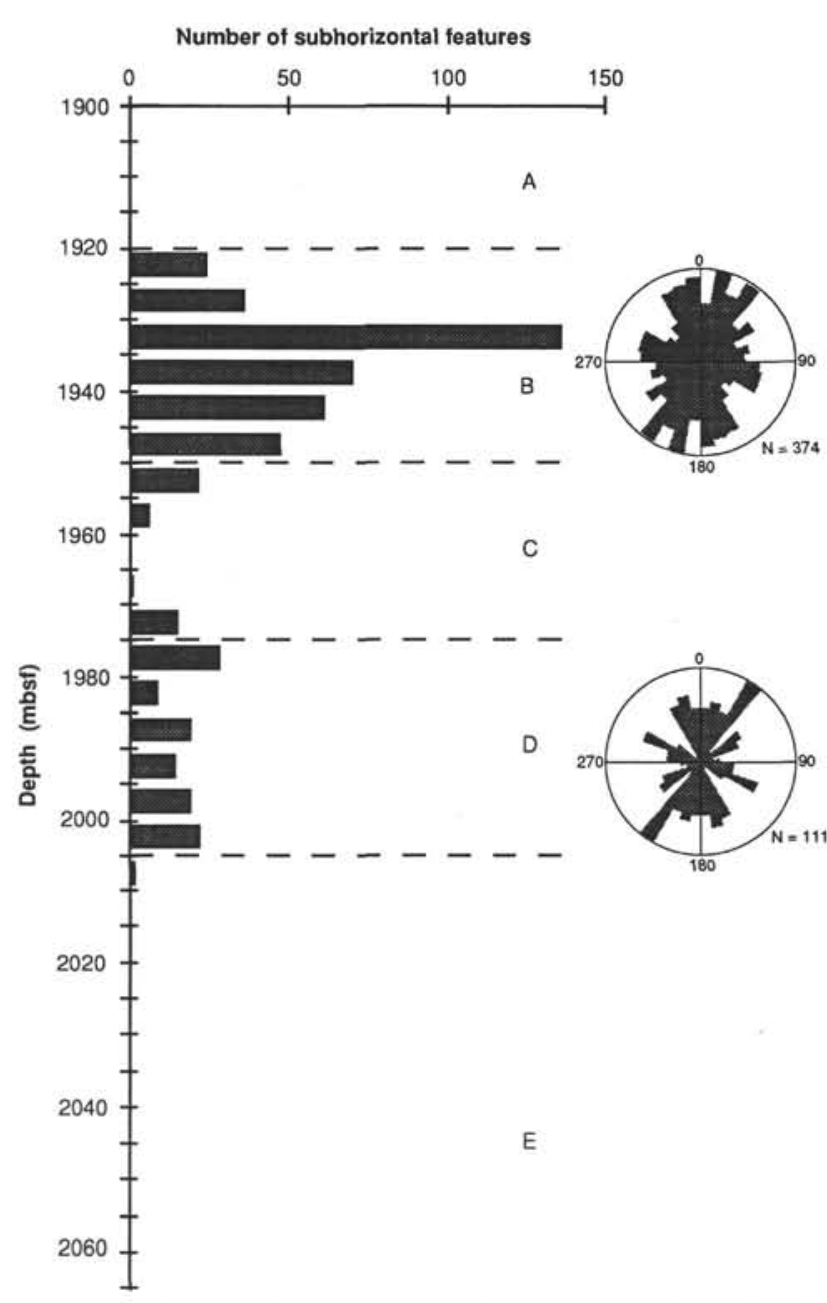

Figure 8. Distribution histogram of subhorizontal features identified in FMS images. Five intervals vs. depth are proposed according to apparent fracture distribution: Zone $\mathrm{A}=1900-1920 \mathrm{mbsf}$, Zone $\mathrm{B}=1920-1950 \mathrm{mbsf}$, Zone C $=1950-1975 \mathrm{mbsf}$, Zone $\mathrm{D}=1975-2005 \mathrm{mbsf}$, and Zone $\mathrm{E}=2005-2080$ mbsf. To the right are corresponding rose diagrams of strike orientations for Zones B and D.

\section{DISCUSSION}

It is convenient to discuss the mapped data set vs. depth, following the zoning described previously. This zoning emphasizes the fact that, both for horizontal (Fig. 8) and for intermediate to subvertical sets (Fig. 10), the dominant strike direction of detected events $\left(015^{\circ} \mathrm{N}\right)$ is generally close to that of maximum horizontal stress direction obtained in the past from the analysis of BHTV images (Newmark et al., 1985; Morin et al., 1990). It is therefore most likely that a substantial number of the planes mapped from FMS images are those created or preferentially reopened under present stress conditions.

The anomaly detected with the DLL between 1980 and 2000 mbsf may also be attributed to the large deviatoric component of the stress field, indicating that the influence of the stress field could extend away from the near vicinity of the borehole. As a consequence, it is most likely that electrical current in our case, or likewise fluid, is or would be biased to flow along this preferential direction $\left(015 \mathrm{~N}^{\circ}\right)$. In the following, geometrical considerations different to those directly related to the maximum horizontal stress direction will be discussed. 

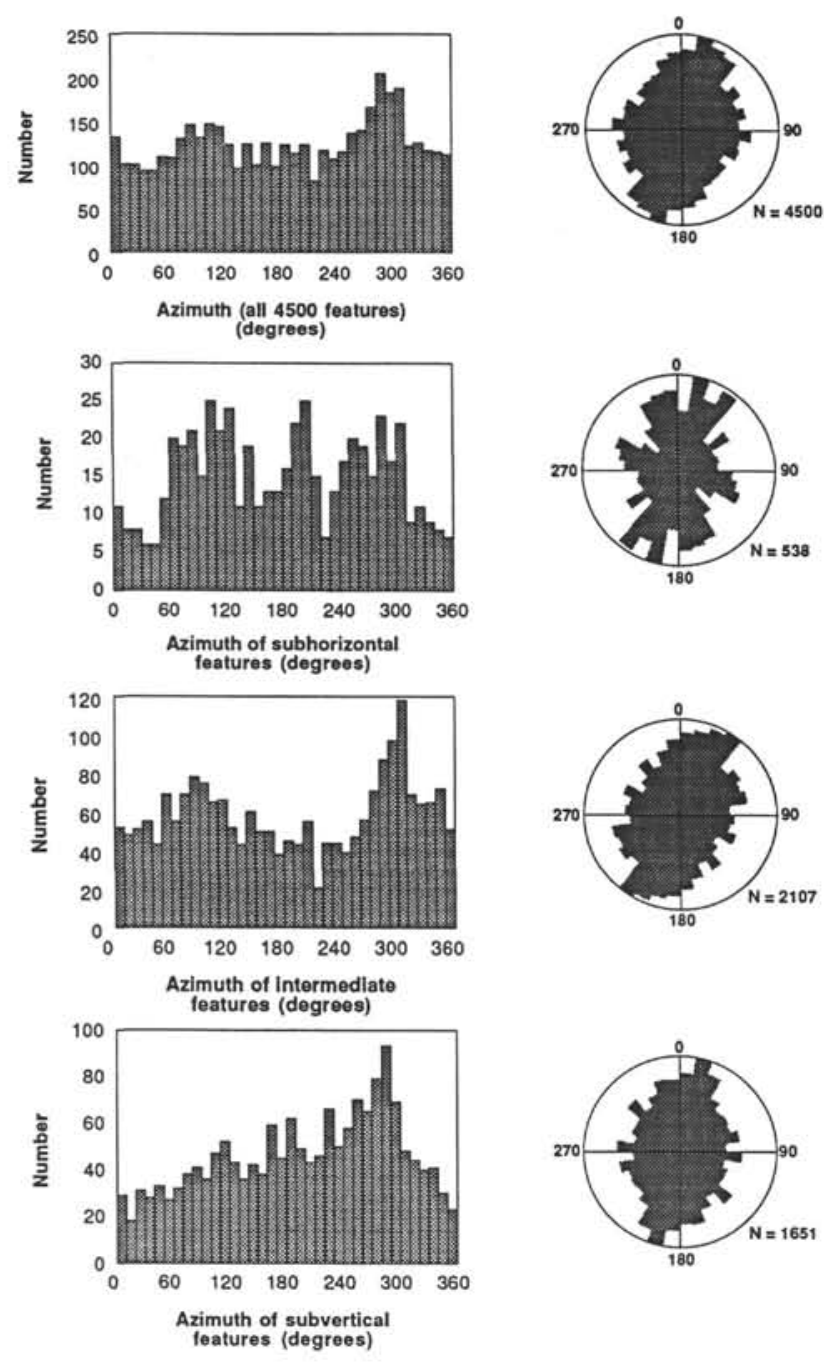

Figure 9. To the left are azimuth histograms of all, subhorizontal, intermediate, and subvertical features selected as per Figure 7. To the right are corresponding rose diagrams of strike orientations.

\section{Zone A (1900-1920 mbsf, 503 Planes, 25.1 per m)}

Zone $\mathrm{A}$ is dominated by features dipping $50^{\circ}$ to $75^{\circ}$ on average (intermediate to subvertical fracture sets) in both DLL and FMS data sets. Two sets trending roughly north-south and northwest-southeast are identified with the FMS, with a peak in fracturing between 1910 and 1915 mbsf (Fig. 10) also seen in the electrical resistivity and velocity data (Fig. 2).

\section{Zone B (1920-1950 mbsf, 1087 Planes, 36.2 per m)}

Zone B, already identified from DLL resistivity measurements as a high-porosity region, can be classified as a fault zone characterized by the presence of numerous horizontal (Fig. 8), but also intermediate and vertical features (Fig. 10). Horizontal planes are more abundant (12.0 per $\mathrm{m}$, on average) than elsewhere in the analyzed interval (Fig. 8). As a consequence, the presence of one or several subhorizontal fault planes in this region might be inferred from these data. Some sets trending northwest-southeast, east-west, and east-northeastwest-southwest are also identified in the steep data set (Fig. 10).

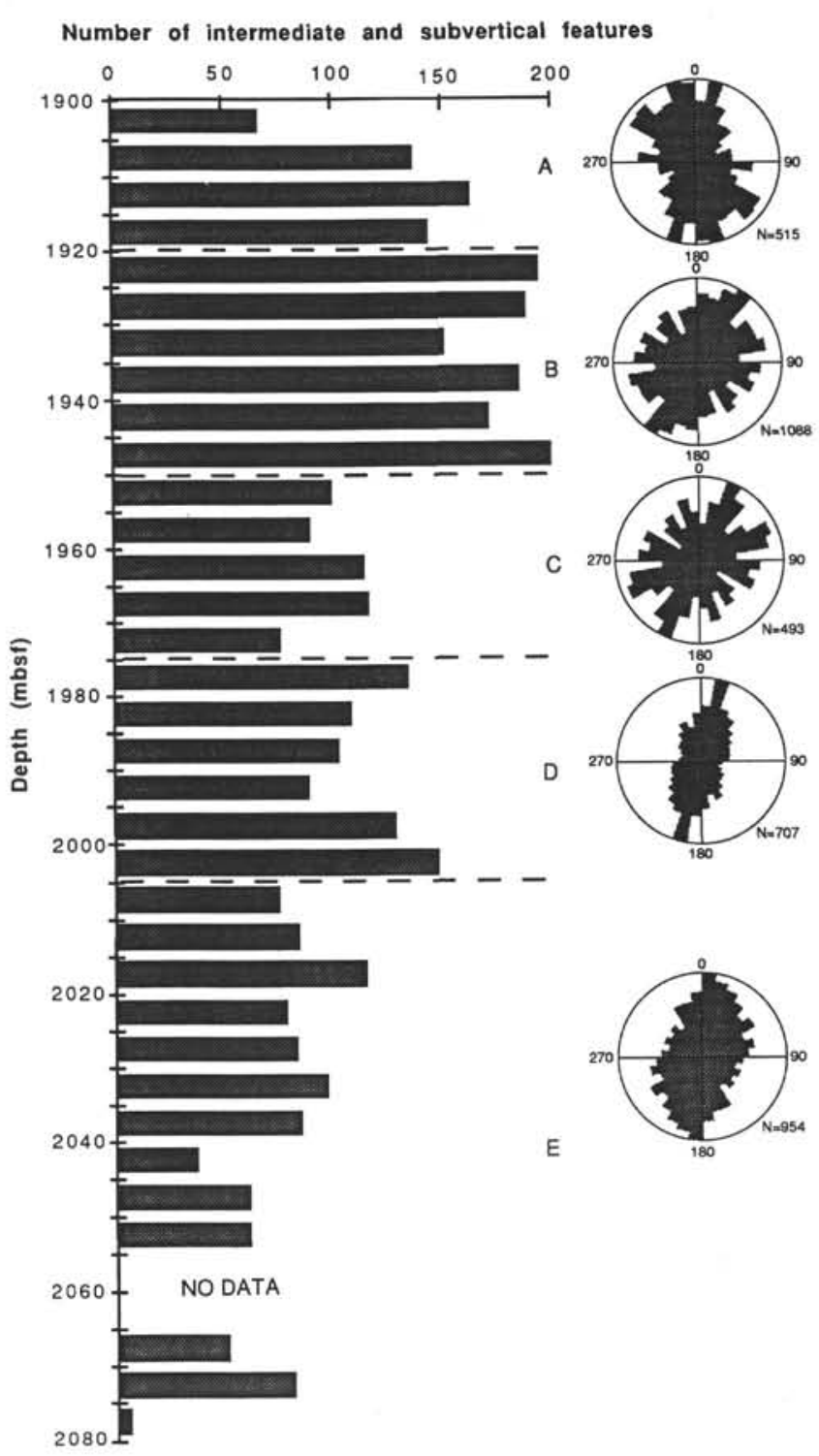

Figure 10. Same as in Figure 8 for intermediate and subvertical features. Steep features with dips $\geq 85^{\circ}$ are not included.

\section{Zone C (1950-1975 mbsf, 494 Planes, 19.8 per m)}

Zone $\mathrm{C}$ is characterized by the absence of subhorizontal planes. Several small sets of intermediate to subvertical features trend in discrete and widely distributed directions, with the larger ones striking east-northeast-west-southwest and east-northeast-west-southwest.

\section{Zone D (1975-2005 mbsf, 809 Planes, 20.2 per m)}

Zone D is characterized by the presence of horizontal fractures (2.7 per $\mathrm{m}$, on average) again with a preferred strike orientation of about $015^{\circ} \mathrm{N}$ (Fig. 8), possibly related to that of the present-day stress field. The deep-reaching DLL measurement shows the presence of numerous subvertical features, more than anywhere else in the analyzed interval. This subvertical fracturing, if developed as it appears in relation to the present-day stress field, might be related to the cool- 


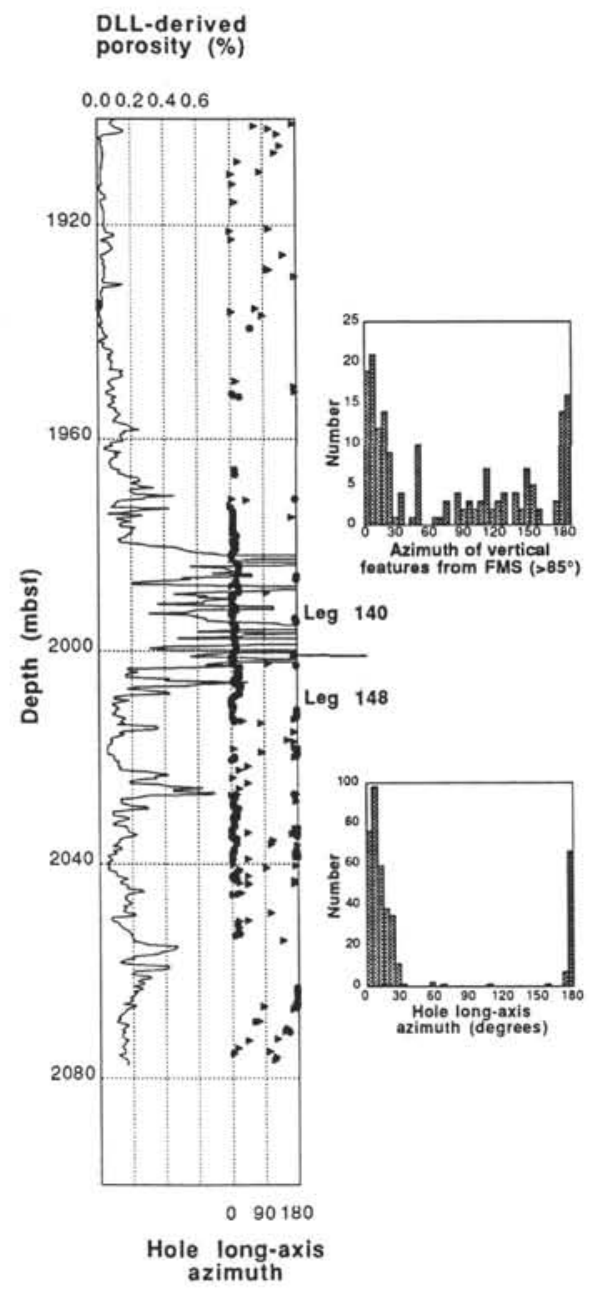

Figure 11. Diagram representing the filtered azimuth of nearly vertical features (dips $\geq 85^{\circ}$, solid triangle) and azimuth of borehole elongations (solid circle) in the bottom $200 \mathrm{~m}$ of Hole 504B (left). The DLL-derived vertical fracture porosity $(\%)$ is presented to the far left. To the right are histograms representing the azimuth of vertical induced features (top) from FMS images and the borehole long-axis. from FMS calipers (bottom).

ing of the hole at the beginning of Leg 148, as it is located in an appropriate manner for such a development of "thermofracs." This hypothesis has been already proposed for the interpretation of BHTV, in higher sections of the borehole, to explain the presence of borehole enlargements in the direction of the maximum horizontal stress (Morin et al., 1990). Such a large degree of fracturing might consequently be induced from the combined action of a strongly deviatoric stress field and the cooling the borehole before coring (to protect the coring bit) or logging (to protect downhole sensors).

\section{Zone E (2005-2080 mbsf, 952 planes, 15.3 per $\mathrm{m}$ )}

Zone $\mathrm{E}$ is also characterized by the presence of vertical and intermediate fractures, but with the smallest density of the analyzed section $\left(15.3\right.$ per $\mathrm{m}$ ). Features trending $015^{\circ} \mathrm{N}$ dominate the data set as in Zone D, which makes any assessment upon the grouping of the rest of the data set difficult at this stage.

\section{Borehole Elongation and Stress}

The hole size measured by the FMS shows large values (often above $15 \mathrm{in}$.) in the upper part of the hole (from the casing shoe down to $1000 \mathrm{mbsf}$ ), and values generally under (12 in.) below $1500 \mathrm{mbsf}$. In the deeper part of Hole 504B, a few narrow intervals near 1700 mbsf, and a 70-m-long section from 1975 to $2045 \mathrm{mbsf}$, are characterized by the presence of large borehole elongations, with values of the long axis of the borehole above (14 in.).

The presence of an elliptical borehole shape is traditionally interpreted in terms of breakouts (Bell and Gough, 1979), with the long axis of the borehole pointing toward the minimum horizontal stress direction. From the analysis of BHTV acoustic data and images of the borehole wall in the upper part of the hole, Morin et al. (1990) derived a main mode of ellipticity pointing $114^{\circ} \mathrm{N}$. This direction was proposed to represent the local minimum horizontal stress direction. A second, less important, but exactly orthogonal, mode of enlargement was also found. It was, as mentioned earlier, attributed to thermal fracturing related to the cooling of the hole by the circulation of cold seawater during drilling.

The caliper measurements obtained with the FMS during Leg 148 generally show a similar bimodal distribution of enlargements, with similar azimuthal orientations at about $015^{\circ} \mathrm{N}$ and $110^{\circ} \mathrm{N}$ (Alt, Kinoshita, Stokking, et al., 1993). For the bottom $200 \mathrm{~m}$ of the hole, borehole elongation azimuths with caliper differences greater than 1.5 in. have been plotted vs. depth with solid circles in Figure 11. Although the depth-azimuth plot does not define these directions extremely well, a histogram of these elongations provides a much clearer description, with a sharp peak at $015^{\circ} \mathrm{N}$ (Fig. 11). This direction might be compared to that of individual nearly vertical fracture trace (with dip $>85^{\circ}$ ) mapped at the borehole surface from FMS images. About 200 such traces were described over the analyzed interval and plotted vs. depth on Figure 11 with solid triangles. The two azimuthal histograms are in excellent agreement, although more scattering is seen in the fracture data set. Moreover, steep fractures and borehole enlargements were found to coincide at depth, in particular over a 70-m-long interval (1975-2045 mbsf).

This large number of nearly vertical features is coherent with the observation of subvertical rupture planes in the core (Alt, Kinoshita, Stokking, et al., 1993), as rupture would certainly be favored along the fracture plane mapped from FMS images. From 1975 to $2005 \mathrm{mb}-$ sf, the large number of subvertical planes detected from DLL data proves that ruptures meeting the borehole surface, and imaged in the long-axis direction of the borehole with the FMS might also extend deeper into the rock. Such strong fracturing at depth into the rock is not present below $2005 \mathrm{mbsf}$, and might therefore be related to the cooling performed before drilling at the beginning of Leg 148 .

\section{CONCLUSIONS}

The detailed analysis of FMS images recorded at the bottom of Hole 504B has provided a very precise description of the fractured massive diabases in sheeted dike complex, with nearly 4500 features mapped over $167 \mathrm{~m}$ of images (26.9 per meter on average). Most of the features trend along a $015^{\circ} \mathrm{N}$ strike direction, which is the orientation of the regional $\mathrm{SH}_{\max }$. The detection of fractures near the borehole surface with the FMS, is obviously favored for those trending in this direction. Such a stress-controlled "reopening" is certainly also true away from the borehole and would affect as well the permeability tensor of the rock, forcing fluid circulation in this $015^{\circ} \mathrm{N}$ direction.

Under the high stresses and temperatures that occur at these depths, borehole enlargements are favored by cooling the hole. Consequently, thermal stresses should, whenever possible, be kept to a 
minimum to avoid a rapid degradation of the borehole surface, with the development of numerous cracks, brittle failure in the $\mathrm{SH}_{\max } \mathrm{di}-$ rection, and the eventual clogging of the drilling assembly as commonly found near the base of Hole 504B.

\section{ACKNOWLEDGMENTS}

We would like to thank Bernard Célérier and Rob Evans for detailed and constructive reviews of this manuscript, as well as Schlumberger Paris for making available the FMS processing and analysis software at academic rates. This work was supported by the "Marine Geosciences" ODP support program of CNRS, in France.

\section{REFERENCES}

Alt, J.C., Kinoshita, H., Stokking, L.B., et al., 1993. Proc. ODP, Init. Repts., 148: College Station, TX (Ocean Drilling Program).

Archie, G.E., 1942. The electrical resistivity log as an aid in determining some reservoir characteristics. J. Pet. Tech., 5:1-8.

Becker, K., 1985. Large-scale electrical resistivity and bulk porosity of the oceanic crust, Deep Sea Drilling Project Hole 504B, Costa Rica Rift. In Anderson, R.N., Honnorez, J., Becker, K., et al., Init. Repts. DSDP, 83: Washington (U.S. Govt. Printing Office), 419-427.

Bell, J.S., and Gough, D.I., 1979. Northeast-southwest compressive stress in Alberta: evidence from oil wells. Earth Planet. Sci. Lett., 45:475-482.

Brace, W.F., Orange, A.S., and Madden, T.R., 1965. The effect of pressure on the electrical resistivity of water-saturated crystalline rocks. J. Geophys. Res., 70:5669-5678.

Dick, H.J.B., Erzinger, J., Stokking, L.B., et al., 1992. Proc. ODP, Init. Repts., 140: College Station, TX (Ocean Drilling Program).

Ellis, D.V., 1987. Well Logging For Earth Scientists: New York (Elsevier).

Hey, R., Johnson, G.L., and Lowrie, A., 1977. Recent plate motions in the Galapagos area. Geol. Soc. Am. Bull., 88:1385-1403.

Langseth, M.G., Cann, J.R., Natland, J.H., and Hobart, M., 1983. Geothermal phenomena at the Costa Rica Rift: background and objectives for drilling at Deep Sea Drilling Project Sites 501, 504, and 505. In Cann, J.R., Langseth, M.G., Honnorez, J., Von Herzen, R.P., White, S.M., et al., Init. Repts. DSDP, 69: Washington (U.S. Govt. Printing Office), 529.

Langseth, M.G., Mottl, M.J., Hobart, M.A., and Fisher, A., 1988. The distribution of geothermal and geochemical gradients near Site 501/504: implications for hydrothermal circulation in the oceanic crust. In Becker, K., Sakai, H., et al., Proc. ODP, Init. Repts., 111: College Station, TX (Ocean Drilling Program), 23-32.

Lüthi, S.M., and Banavar, J.R., 1988. Application of borehole images to three-dimensional geometric modeling of eolian sandstone reservoirs, Permian Rotliegende, North Sea. AAPG Bull., 72:1074-1089.

Lüthi, S.M., and Souhaité, P., 1990. A method for fracture extraction and width determination from electrical borehole scans. Geophysics, 55:821833.

Moos, D., and Zoback, M.D., 1990. Utilization of observations of well bore failure to constrain the orientation and magnitude of crustal stresses: application to continental, Deep Sea Drilling Project, and Ocean Drilling Program boreholes. J. Geophys. Res., 95:9305-9325.

Morin, R.H., Newmark, R.L., Barton, C.A., and Anderson, R.N., 1990. State of lithospheric stress and borehole stability at Deep Sea Drilling Project Site 504B, eastern Equatorial Pacific. J. Geophys. Res., 95:9293-9303.

Newmark, R.L., Anderson, R.N., Moos, D., and Zoback, M.D., 1985. Sonic and ultrasonic logging of Hole 504B and its implications for the structure, porosity, and stress regime of the upper $1 \mathrm{~km}$ of the oceanic crust. In Anderson, R.N., Honnorez, J., Becker, K., et al., Init. Repts. DSDP, 83: Washington (U.S. Govt. Printing Office), 479-510.

Pezard, P.A., 1990. Electrical properties of mid-ocean ridge basalt and implications for the structure of the upper oceanic crust in Hole 504B. J. Geophys. Res., 95:9237-9264.

Pezard, P.A., and Anderson, R.N., 1990. Electrical resistivity, anisotropy, and tectonic context. Trans. SPWLA, Paper M, 31st Annu. Log. Symp. Lafayette, LA, USA.

Pezard, P.A., Lovell, M., and Ocean Drilling Program Leg 126 Shipboard Scientific Party, 1990. Downhole images: electrical scanning reveals the nature of subsurface oceanic crust. Eos, 71:710.

Date of initial receipt: 23 August 1994

Date of acceptance: 22 February 1995

Ms 148SR-152 